\title{
STRATEGI PENGEMBANGAN SITUS MANUSIA PURBA SANGIRAN SEBAGAI DAYA TARIK WISATA BUDAYA
}

\author{
Enny Mulyantari \\ Dosen Sekolah Tinggi Pariwisata AMPTA Yogyakarta \\ Email : ennymulyantari@yahoo.co.id
}

\begin{abstract}
Tourism proved to contribute in the acceptance of local revenues and plays a role in alleviating poverty. Tourism also plays a role in efforts to improve the nation's identity and encourage awareness and community pride of the natural and cultural wealth. With the tourism, a country or more specifically of local government where it is located, will get revenue from the income of each tourism destination. Potential tourism attraction in Sangiran, Sragen has not fully optimally managed, so that the existence of a tourism asset has not received the maximun response from visitors in the form of tourist visits.

The problem in this research is how the potential of cultural tourism Sangiran site and what strategies are applied to the future development of Sangiran Site as a tour. This research aims to find the strategies in Sangiran tourism development according with the character as world heritage site. This research uses SWOT analysis, to find strengths weaknesses factors, opportunities and challenges faced in the development of these attractions. This research is a qualitative which look at research as a process, in order to gain a deep understanding with regard to community interaction in the area of research, Sangiran Site, Kalijambe, Sragen, Central Java Province.

The results shown that as rated world's cultural heritage, tourism development position Sangiran located in a strategic position, if it is able to use optimally the power and opportunities that it has. One strength of tourist object is because of the uniqueness and rarity, as shown by a collection of objects on display in the Museum of Ancient Man Sangiran. The cultural heritage objects, dating from prehistoric times, either in the form of early human fossils millions of years old, as well as other antique objects which the old is hundreds years old is very important to understand the life of the ancestors of Indonesia in the past.

Efforts to prevent the theft of Sangiran Site's fossils, so in addition to the on going elucidation of the importance of cultural heritage, legal sanctions should be enforced, due to the exploitation of fossil violating Republic Act No. 11 Year 2010 About the Cultural Heritage. Therefore, it is considered important and urgent, in order to be formed Awareness group as one component in society which have an important role and contribution in the development tourism of Sangiran Site.
\end{abstract}

Keywords: Strategic,Development,Tourist object,Cultural Heritage.

\section{PENDAHULUAN}

Pada dasawarsa terakhir ini pariwisata semakin berperan penting dalam berbagai macam dimensi kehidupan manusia. Tidak dapat dipungkiri, bahwa pariwisata meru- pakan sektor yang paling menyentuh seluruh aspek kehidupan masyarakat, baik dalam bidang bisnis, pelayanan pemerintahan, lingkungan alam, dan budaya. Salah satu dampak ekonomi yang dapat dilihat adalah sektor pariwisata mampu 
menjadi penyumbang devisa sebesar lebih dari US\$ 10 juta bagi Indonesia atau terbesar ke 4 pada periode 2013 di bawah minyak dan gas bumi, batu bara dan minyak kelapa sawit (Maulana 2014:133).

Di Indonesia berbagai jenis wisata yang dapat ditawarkan kepada wisatawan antara lain, wisata alam, wisata budaya, wisata belanja, wisata rohani dan bahkan wisata kuliner, karena itu tidak mengherankan apabila Indonesia dijadikan destinasi wisata dunia oleh berbagai wisatawan dunia. (Pitana 2005:110) menjelaskan bahwa daya tarik wisata merupakan komponen yang vital karena merupakan faktor penyebab utama mengapa orang mengunjungi daerah wisata.

Badan Pariwisata Dunia (World Tourism Organization/WTO) memperkirakan bahwa di dalam mega kegiatan wisata di dunia, setidaknya $40 \%$ penggerak motivasi perjalanan wisatawan adalah karena faktor budaya. Fakta seperti ini, menjadikan kita selayaknya bangga, karena terbukti budaya memiliki potensi untuk menjadi sumber daya industri terbesar di dunia (Nuryanti, 2004: tanpa halaman). Dalam konteks demikian ini, hubungan antara pemanfaatan warisan budaya melalui pariwisata tidak bisa tidak harus diperhitungkan.

Indonesia juga dikenal sebagai negara yang kaya akan warisan budayanya, namun demikian, tidak semua keanekaragaman budaya tersebut berada dalam kondisi yang optimal, apalagi jika dikaitkan dengan pariwisata yang mengharapkan memiliki nilai jual yang layak. Sebagian besar diantaranya, warisan budaya kita dalam kondisi sangat memprihatinkan dari berbagai aspek, baik aspek kurangnya perawatan dan kepedulian, sehingga rusak dan hancur bahkan sebagian musnah oleh perilaku pewarisnya sendiri, oleh karena itu, diperlukan strategi tersendiri dalam pemanfaatan warisan budaya sebagai daya tarik wisata.

Di Provinsi Jawa Tengah banyak terdapat aset wisata, baik aset wisata alam, aset wisata buatan manusia maupun aset wisata yang bersifat manusiawi. Salah satu aset wisata buatan manusia (man made resources) adalah Situs Sangiran yaitu berupa kawasan situs prasejarah. Potensi kuat atau daya tarik Sangiran terletak pada kandungan fosi-fosil hewan maupun manusia purba dan peralatan batu serta terdokumentasikannya lapisan tanah (stratigrafi) yang tidak terputus sejak dua juta tahun yang silam dan banyak menyumbangkan data bagi pemahaman evolusi fisik manusia maupun linkungan alam purba (Widianto dkk. 2011: 10). Sejak Desember tahun 1996 Sangiran sudah ditetapkan sebagai World Heritage atau warisan dunia oleh UNESCO, karena potensinya yang langka tersebut. Potensi yang langka seperti tersebut oleh Pemerintah Daerah dipandang tepat untuk dikembangkan sebagai destinasi wisata unggulan yang diharapkan dapat mendatangkan devisa yang pada akhirnya dapat menyejahterakan masyarakat.

Sejalan dengan Rencana Induk Pelestarian Kawasan Situs Sangiran, khususnya di bidang pemanfaatan dalam hal edukasi, ilmu pengetahuan, dan pariwisata, pengembangan museum-museum yang menampilkan informasi mengenai temuan-temuan fosil terbaik, serta hasilhasil budaya manusia Sangiran bagi masyarakat luas sebagai daya tarik wisata terus dilakukan, sehingga masyarakat dapat merasakan akan nilai penting Situs Sangiran sebagai World Heritage dan potensi di dalamnya. Di Sangiran daya tarik wisata yang lain belum dikembangkan secara optimal, baik dari segi pembangunan 
fisik yang meliputi prasarana dan sarananya (penginapan, tempat makan dan minum, angkutan wisata), fasilitas umum, potensi tujuan wisata (atraksi wisata) maupun industri pariwisata secara keseluruhan. Sangiran mempunyai daya tarik wisata yang perlu dikaji untuk dikembangkan di masa yang akan datang, potensi wisata (daya tarik wisata) tersebut adalah sumber air asin, industri batik, ekowisata. Disisi lain, kondisi sosial budaya penduduk Sangiran belum siap menerima perubahan yang ditimbulkan oleh kemajuan di bidang pariwisata, karena persepsi masyarakat belum berkembang terhadap bisnis dan industri pariwisata.

Untuk menuju ke tujuan pengembangan pariwisata yang terintegrasi, terencana, dan secara menyeluruh, harus dilaksanakan secara terpadu oleh para pemangku kepentingan atau stakeholder agar tidak terjadi konflik antara pelestarian di satu sisi dengan kepariwisataan di sisi yang lain, sehingga dapat dimanfaatkan oleh masyarakat baik dari segi ekonomi, sosial dan budaya. Informasi pariwisata agar Sangiran semakin terkenal di masyarakat luas perlu dikemas dan dilakukan secara tersendiri. Bedasarkan latar belakang masalah tersebut di atas, penulis akan membahas tentang Strategi Pengembangan Situs Manusia Purba Sangiran Sebagai Daya Tarik Wisata Budaya.

\section{LANDASAN TEORI}

\section{Strategi Pengembangan}

Manajemen Strategi yaitu suatu rangkaian aktivitas terhadap pengambilan keputusan yang dibuat oleh pimpinan dan juga dilaksanakan oleh seluruh pihak-pihak yang terlibat di dalam suatu perusahaan dalam mencapai tujuan yang diharapkan.
Strategi adalah suatu kegiatan merancang kegiatan agar strategis serta berhasil memperoleh hasil yang lebih baik. Keberhasilan tersebut haruslah selalu menjadi pedoman dan harus dilakukan evaluasi terhadapnya untuk mengetahui apakah benar-benar telah sesuai dengan tujuan yang ingin diraihnya (Gitosudarmo 2001:12).

Pengertian pengembangan dijelaskan oleh Winardi (2013:114-115) yaitu proses, cara, perbuatan menjadikan maju atau pembangunan secara bertahap, teratur dan berkelanjuntan, yang menjurus ke sasaran yang dikehendaki. Pengembangan juga dapat dinilai sebagai respon terhadap perubahan yang selalu terjadi dari waktu ke waktu.

Dengan demikian, dapat disimpulkan bahwa strategi pengembangan merupakan suatu rangkaian aktivitas pengambilan keputusan untuk upaya kemajuan ke arah yang lebih baik secara bertahap, terencana, teratur dan berkelanjutan, yang menjurus ke sasaran yang dikehendaki.

Pengembangan kepariwisataan bertujuan memberikan keuntungan baik bagi wisatawan maupun warga setempat. Pariwisata dapat memberikan kehidupan yang standar kepada warga setempat melalui keuntungan ekonomi yang didapat dari tempat tujuan wisata. Pada perkembangan infrastruktur dan fasilitas rekreasi, keduanya menguntungkan wisatawan dan warga setempat, sebaliknya kepariwisataan dikembangkan melalui penyediaan tempat tujuan wisata (Marpaung 2002:19). Konsep pengembangan tersebut, dilakukan melalui pemeliharaan kebudayaan, sejarah dan daya tarik wisata lain sesuai dengan potensi yang dimiliki.

Teknik pengembangan destinasi pariwisata memerlukan teknik perencanaan yang baik dan tepat, lebih lanjut Pitana 
(2009:134) menjelaskan bahwa teknik pengembangan harus menggabungkan beberapa aspek penunjang. Aspek-aspek tersebut adalah aspek aksesibilitas (transportasi dan saluran pemasaran), karakteristik infrastruktur pariwisata, tingkat interaksi sosial, keterkaitan/ kompatibilitas dengan sektor lain, daya tahan akan dampak pariwisata, tingkat resistensi komunitas lokal, dan seterusnya.

Model pariwisata budaya di Indonesia sekarang ini adalah model pariwisata yang berkesinambungan atau sustainable cultural-tourism (Suranti, 2005:7). Model pariwisata yang demikian ini tidak sematamata bertujuan untuk mendapatkan pemasukan, akan tetapi juga peduli terhadap dampak yang ditimbulkan baik bagi masyarakat maupun terhadap daya tarik wisata. Model tersebut berkembang sebagai reaksi terhadap dampak negatif dari pariwisata yang terlalu menekankan tujuan ekonomi semata, tanpa memperdulikan kekelestarian warisan budaya.

Pengembangan Situs Sangiran diperlukan agar Situs Sangiran yang banyak mengandung fosil-fosil hewan maupun manusia purba dan perlatan batu serta terdokumentasinya lapisan tanah (sratigrafi) yang tidak terputus sejak dua juta tahun yang silam ini dapat menjadi daya tarik wisata unggulan. Pengembangan Situs Sangiran sebagai daya tarik wisata unggulan diharapkan pula dapat mendatangkan devisa yang akhirnya dapat menyejahterakan masyarakat.

\section{Daya Tarik Wisata Budaya}

Tempat yang dikunjungi oleh wisatawan merupakan tempat-tempat yang memiliki daya tarik tinggi, sehingga wisatawan tertarik untuk mengunjunginya. Tempat-tempat tersebut yang dikenal dengan istilah daya tarik wisata, dan merupakan salah satu komponen utama dalam kegiatan pariwisata. Di dalam Undang-Undang Republik Indonesia Nomor: 10 Tahun 2009 Tentang Kepariwisataan lebih lanjut disebutkan bahwa yang dimaksud dengan Daya Tarik Wisata adalah segala sesuatu yang memiliki keunikan, keindahan, dan nilai yang berupa keanekaragaman kekayaan alam, budaya, dan hasil buatan manusia yang menjadi sasaran atau tujuan kunjungan wisatawan. Ismayanti (2010:147) menyebutkan, kegiatan wisata di sebuah wilayah tidak lengkap tanpa daya tarik wisata atau tourist attraction dan merupakan fokus utama dari industri pariwisata. Usaha daya tarik wisata kegiatannya adalah membangun dan mengelola daya tarik wisata beserta prasarana dan sarana yang diperlukan atau mengelola daya tarik yang telah ada.

Jenis daya tarik wisata akan memberikan pengalaman dan kepuasan tersendiri bagi wisatawan. Salah satu jenis daya tarik wisata menurut Pendit (2003:38) dalam bukunya yang berjudul "Ilmu Pariwisata Sebuah Pengantar Perdana" wisata budaya yakni merupakan perjalanan yang dilakukan atas dasar keinginan untuk memperluas pandangan hidup dengan jalan mengadakan kunjungan atau peninjauan ke tempat lain, mempelajari keadaan rakyat, kebiasaan dan adat istiadat mereka, cara hidup, budaya dan seni mereka.

Dengan mempertimbangkan bahwa daya tarik utama Situs Sangiran adalah fosil-fosil sebagai warisan budaya memberikan inspirasi baru bagi Pemda setempat untuk mengeluarkan kebijakan bahwa Sangiran dipandang sangat tepat untuk dikembangkan sebagai daya tarik wisata budaya, khususnya untuk pengembangan pengetahuan sejarah evolusi manusia (Anonim, 2002:13), hal ini dikarenakan kecenderungan pasar pariwisata sekarang, 
baik nasional maupun internasional adalah wisata budaya.

\section{METODE PENELITIAN}

Objek penelitian ini adalah strategi pengembangan Situs Sangiran sebagai daya tarik wisata budaya. Penelitian ini berusaha untuk menemukan dan memahami apa yang ada di balik fenomena yang akan diteliti pada periode tertentu dan dalam kondisi yang alamiah, sehingga metode yang digunakan adalah metode kualitatif. Untuk menganalisis strategi pengembangan Situs Sangiran pada kondisi yang alamiah, maka metode pengambilan data dilakukan dengan pengamatan, dokumentasi, penelusuran dan studi pustaka.

\section{HASIL DAN PEMBAHASAN}

Analisis SWOT (Strength, Weaknes, Opportunity, Threat) kawasan Situs Sangiran dilakukan untuk menemukenali faktor-faktor kekuatan, kelemahan, dan peluang serta tantangan yang dihadapi dalam pengembangan situs. Adapun faktorfaktor internal dan eksternal Situs Sangiran adalah sebagai berikut.

\section{Hasil Temuan}

\section{a. Kekuatan (strengths)}

Sebagai wilayah pengembangan pariwisata, Situs Sangiran memiliki kekuatan-kekuatan (strengths) yang dapat dijadikan modal pengembangan. Secara stratigrafis dan arkeologis, lapisan tanah di Situs Sangiran tersusun secara berurutan tanpa putus sejak 2 juta tahun yang lalu hingga sekitar 200.000 tahun yang lalu dan merupakan situs manusia purba terlengkap di Asia berupa fosil-fosil hewan dan manusia purba yang berumur 2 juta tahun yang pernah tinggal di pulau Jawa. Sangiran merupakan destinasi wisata yang unik, menarik, dan langka keberadaannya, oleh karena itu situs ini mendapat pengakuan dari UNESCO sebagai warisan budaya dunia, sehingga memudahkan pencarian dana guna pengembangan situs. Sebagai warisan budaya dunia kepedulian pemerintah dengan dibantu komitmen antar stakeholder untuk memajukan pariwisata Sangiran sangat kuat. Komitmen dari orang-orang penting pembuat keputusan adalah hal yang vital guna mensinergikan program-program pengembangan kepariwisataan (Bryson 2007:85). Selain itu keberadaan Situs Sangiran telah dilindungi oleh Negara dengan dasar hukum yang kuat yaitu Undang-Undang No. 11 Tahun 2010 tentang Cagar Budaya. Aksesibilitas maupun sarana dan prasarana cukup baik, sehingga memudahkan unntuk dikunjungi. Situs Sangiran berada tidak jauh dari pusat kota Surakarta $(14 \mathrm{Km})$, dan hanya berjarak sekitar $10 \mathrm{Km}$ bandara internasional Adi Sumarmo. Selain itu memiliki sarana dan prasarna fisik yang cukup lengkap seperti jaringan listrik, telepon, internet, serta kondisi jalan yang relatif bagus, khususnya di Museum Klaster Krikilan. Disamping itu, terdapat beberapa kelompok home industry atau kerajinan rakyat antara lain meliputi perajin cindera mata batu, perajin anyaman bambu, perajin kancing dari batok kelapa, perajin meubeler dari kayu, dan perajin batik mampu membantu peningkatan perekonomian mereka.

\section{b. Kelemahan (weakness)}

Terdapat beberapa faktor yang merupakan kelemahan (Weakness), sekaligus menjadi faktor internal dalam proses pengembangan wisata Sangiran. Sebagai situs bertaraf dunia, Sangiran masih terbatas jumlah pengunjungnya, hal ini disebab- 
kan antara lain karena belum optimalnya upaya promosi dan kerja sama dengan Biro Perjalanan Wisata.

Peran serta masyarakat Sangiran untuk mempengaruhi kesuksesan perkembangan pariwisata masih lemah, padahal masyarakat merupakan elemen penting dalam mengembangkan destinasi wisata., karena secara tidak langsung upaya pengembangan pariwisata akan berdampak pada peningkatan kesejahteraan masyarakat sekitar itu sendiri.

Di wilayah Sangiran, belum ada kelompok sadar wisata, oleh karena itu penyuluhan mengenai arti penting kepariwisataan belum pernah dilakukan. Minimnya tenaga profesional dalam pengelolaan daya tarik wisata khususnya Klaster Ngebung, Bukuran, dan Manyarejo menyebabkan berbagai kendala kurang dapat diatasi.

Faktor lain yang menjadi kelemahan adalah aksesibiltas khususnya menuju ke ketiga Klaster (Ngebung, Bukuran dan Manyarejo) tidak memadai, rusak dan sempit sehingga sukar dilewati bus, serta tidak adanya transportasi umum menuju ke ketiga klaster tersebut. Museum Klaster Krikilan lahan parkir tidak memadai untuk menampung beberapa bus pariwisata yang besar. Rumah makan ataupun warung makan yang berstandar baik belum tersedia. Toko-toko yang menyediakan cindera mata sebagai bagian dari pariwisata masih perlu ditata, baik tempat maupun penataan barang-barang yang dipajang.

Atraksi wisata seperti pergelaran kesenian sangat jarang diselenggarakan kecuali ada momen tertentu yang penting, masih mempunyai banyak potensi sumber daya yang belum digali dan diidentifikasi serta dieksplorasi, yang dapat dikembangkan sebagai objek dan daya tarik wisata.
Penduduk Sangiran beranggapan bahwa fosil memiliki nilai ekonomis yang besar, sehingga fosil sebagai warisan yang dilindungi oleh negara sering diperdagangkan secara illegal.

Kelemahan terakhir adalah status kepemilikan tanah di wilayah Situs Sangiran sebagian besar masih milik masyarakat. Kondisi ini agak mengganggu pemerintah dalam upaya pengembangan Situs Sangiran ke depan.

\section{c. Peluang (opportunities)}

Dalam penyusunan strategi pengembangan suatu wilayah, disamping mempertimbangkan faktor-faktor internal, juga penting memperhatikan faktor-faktor eksternal. Peluang adalah situasi yang menguntungkan industri pariwisata Berbagai peluang eksternal yang ada di Situs Sangiran. Perhatian serius dari pemerintah, baik pemerintah pusat maupun daerah yang mencanangkan Situs Sangiran sebagai destinasi wisata unggulan, secara optimal berupaya melakukan pengembangan dan memiliki peluang untuk berkembang di masa depan.Kondisi keamanan wilayah Sangiran, relatif aman, karena berada di pedesaan yang menjunjung tinggi nilai-nilai ke timuran ( baca keJawaan). Dukungan dana anggaran yang relatif cukup, karena baik pemerintah pusat maupun daerah, masing-masing secara bergotong royong menyediakan dana untuk kepentingan pengembangan situs dan Museun Sangiran. Pesatnya perkembangan ilmu pengetahuan dan teknologi sekarang ini telah berimplikasi pada pengembangan suatu destinasi wisata.

\section{d. Hambatan/Ancaman (threat)}

Selain adanya peluang-peluang yang merupakan faktor ekesternal, pengembangan pariwisata, sudah pasti terdapat 
ancaman yang menghambat proses pengembangan yang perlu dicari solusinya. Ancaman kawasan pariwisata merupakan situasi yang tidak menguntungkan industri pariwisata dalam lingkungan suatu kawasan pariwisata. Adanya pengaruh globalisasi yang telah memasuki wilayah tradisional masyarakat sampai ke pedesaan, nilai-nilai budaya masyarakat yang sebelumnya dijunjung tinggi secara perlahan nilainya mulai menurun,dan menimbulkan adanya sikap komersial masyarakat.

Adanya alih fungsi lahan dari fungsi pertanian produktif menjadi lahan perumahan dan bangunan perkantoran (permuseuman) mengakibatkan berkurangnya lahan terbuka hijau, sehingga mengurangi keasrian alam.

Angkutan umum menuju Sangiran sangat terbatas, khususnya dari kecamatan menuju ke situs, pengunjung yang tidak membawa kendaraan pribadi harus menunggu kendaraan angkutan pedesaan yang datangnya tidak setiap waktu. Khusus museum pendukung Manyaerejo dan museum klaster Bukuran dan klaster Ngebung tidak mudah dijangkau , karena lokasinya berada di pelosok pedesaan yang jauh dari keramian kota. Keberadaan museum ini nyaris tidak diketahui orang dan jauh dari fasilitas umum, sehingga berdampak pada sepinya pengunjung.

Berbagai kasus pencurian fosil di Situs Sangiran masih sering terjadi dengan pelaku penduduk setempat yang sudah mengetahui secara detail situasi dan kondisi wilayah Situs Sangiran.

Tenaga profesional khususnya yang berada di museum pendukung Manyarejo, museum klaster Bukuran, klaster Ngebung, dan museum klaster Dayu, sangat terbatas dan kurang profesional.

\section{Strategi Pengembangan}

Dari kedua faktor internal dan eksternal yang dijabarkan dalam kekuatan, kelemahan, peluang, serta hambatan tersebut, diperoleh beberapa strategi yang dikenal dengan nama strategi SWOT. Strategi tersebut terdiri atas strategi SO (Kekuatan-Kesempatan), strategi WO ( kelemahan dan kesempatan), strategi ST (Kekuatan-Ancaman), dan strategi WT atau Strategi Kelemahan-Ancaman (Rangkuti 2006:31). Strategi tersebut dipergunakan untuk menganalisa strategi pengembangan Situs Sangiran. Strategi tersebut dipergunakan untuk menganalisis strategi pengembangan Situs Manusia Purba Sangiran seperti terlihat pada matriks di bawah ini. 


\section{Gambar Matriks SWOT}

\begin{tabular}{|c|c|c|}
\hline & $\begin{array}{l}\text { Kekuatan (S) } \\
\text { 1. Potensi Stratigrafis } \\
\text { 2. Potensi Arkeologis } \\
\text { 3. Warisan Dunia } \\
\text { 4. Aksesibilitas } \\
\text { 5. Tingginya Kepedulian } \\
\text { Pemerintah } \\
\text { 6. Amenitas } \\
\text { 7. Dilindungi Undang-Undang } \\
\text { Cagar Budaya } \\
\text { 8. Kerajinan Rakyat } \\
\text { 9. Daya Tarik Wisata yang } \\
\text { Unik }\end{array}$ & 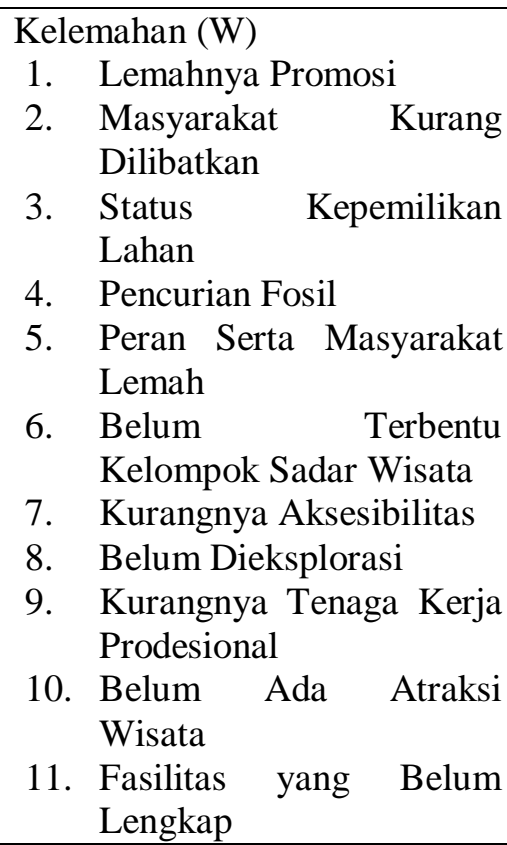 \\
\hline \begin{tabular}{ll}
\multicolumn{2}{l}{ Peluang $(\mathrm{O})$} \\
1. & Kebijakan Pemerintah \\
& dalam Pengembangan \\
& Situs Sangiran \\
2. Jaminan Keamanan \\
3. \\
4. & Sersedianya Anggaran \\
& Teknologi Informasi
\end{tabular} & $\begin{array}{l}\text { Strategi S-O } \\
\text { 1. Pengelolaan Potensi Wisata } \\
\text { Budaya } \\
\text { 2. Peningkatan Kualitas Produk } \\
\text { 3. Edukatif dan Informatif } \\
\text { 4. Komersial }\end{array}$ & 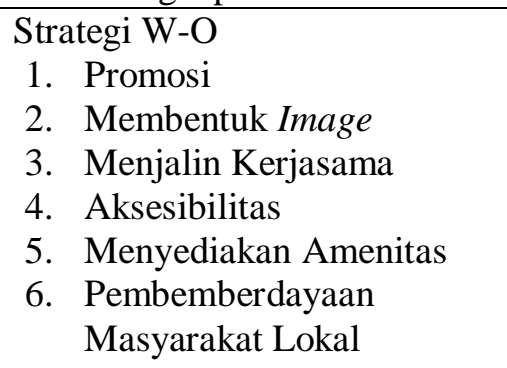 \\
\hline $\begin{array}{l}\text { Ancaman (T) } \\
\text { 1. Menurunnya Nilai-Nilai } \\
\text { 2. Adanya Alih Fungsi } \\
\text { Lahan Pertanian } \\
\text { 3. Keterbatasan Transportasi } \\
\text { Umum } \\
\text { 4. Masih Adanya Pencurian } \\
\text { Fosil } \\
\text { 5. Lokasi Terpencil } \\
\text { 6. Minimnya Sumber Daya } \\
\text { Manusia yang Profesional }\end{array}$ & $\begin{array}{ll}\text { Strategi S-T } \\
\text { 1. } & \text { Penambahan Pegawai } \\
\text { 2. } & \text { Membentuk Kelompok } \\
& \text { Sadar Wisata } \\
\text { 3. } & \text { Peran Serta Masyarakat } \\
\text { 4. } & \text { Investor }\end{array}$ & $\begin{array}{ll}\text { Strategi W-T } \\
\text { 1. } \\
\text { 2. Pasilitas Parkir } \\
\text { 3. Peninatan Stakeholders } \\
\text { Manusia } \\
\text { 4. } & \text { Penegakan Hukum }\end{array}$ \\
\hline
\end{tabular}

Hasil dari matriks SWOT didapatkan alternatif strategi sebagai berikut.

\section{a. Strategi Strength and Opportunities}

Strategi SO merupakan strategi yang menggunakan kekuatan-kekuatan (strength) untuk memanfaatkan peluang (Opportunities) yang ada. Strategi SO dalam pengembangan lokasi wisata dirumuskan dengan menggunakan berbagai kekuatan yang ada diantaranya adalah meningkatkan pengelolaan potensi secara serius, dengan menonjolkan bahwa Situs Sangiran sebagai warisan dunia yang sudah diakui oleh UNESCO, sehingga mampu menarik perhatian investor.

Kualitas produk wisata tidak lepas dari peranan pelaku wisata. Para aktor pelaku yang berperan dalam pengelolaan kepariwisataa Situs Sangiran, pada era globalisasi ini tidak dapat lagi sebagai 
pelaku amatiran, tetapi harus memiliki kemampuan profesionalitas yang tinggi, tidak hanya mengetahui teori tapi mampu mengaplikasikan dalam tindakan operatif, agar produk yang dihasilkan memiliki nilai jual yang tinggi.

Daya tarik wisata Situs Sangiran memberikan nilai-nilai edukatif dan informatif, di samping rekreatif yang menghibur, sehingga mampu memberikan atmosfer dan suasana yang khas dan menyenangkan bagi wisatawan. Dalam hal ini, pengunjung tentu akan merasa nyaman dan terhibur.

Daya tarik wisata budaya Sangiran memiliki nilai-nilai komersial yang akan mampu menarik minat wisatawan untuk datang berkunjung, namun demikian harus ada jaminan bahwa waktu dan biaya yang telah mereka keluarkan senilai dengan pengalaman yang diperoleh setelah mengunjungi objek tersebut.

\section{b. Strategi Weaknesses Opportunities}

Strategi WO merupakan strategi yang meminimalkan kelemahan untuk memanfaatkan peluang. Strategi WO dalam pengembangan destinasi wisata di Sangiran adalah meningkatkan penyelenggaraan promosi mengenai Warisan Dunia Situs Sangiran dengan segala potensi dan keunikannya. Promosi ini dapat dilakukan secara terus menerus dengan mengadakan even-even wisata, melalui Biro Perjalanan Wisata dan brosur-brosur di berbagai media massa cetak maupun elektronik, upaya ini diharapkan dapat meningkatkan jumlah kunjungan wisatawan baik nusantara maupun mancanegara.

Membentuk image bahwa Situs Sangiran sebagai salah satu daya tarik wisata budaya yang unik dengan cara memasyarakatkan pariwisata, sekaligus mempariwisatakan masyarakat sekitar. Hal ini dapat dilakukan secara terus menerus mengajak masyarakat untuk berperan aktif dalam pariwisata di daerah ini, dengan memanfaatkan aktivitas sosial masyarakat untuk tujuan pariwisata, mengadakan berbagai pertunjukkan kesenian sehingga wisatawan akan tertarik untuk menyaksikannya. Pemberdayaan masyarakat lokal dengan cara menciptakan wadah atau organisasi pengelolaan tempat wisata. Organisasi sebaiknya dapat dibentuk oleh masyarakat setempat, bekerja sama dengan pemerintah yang nantinya akan dapat merumuskan segala sesuatu mengenai pengembangan pariwisata di wilayah mereka.

Meningkatkan kerjasama dengan stake holders, pemangku kepentingan, yang berkompeten dengan pariwisata seperti, Biro Perjalanan Wisata, organisasiorganisasi pariwisata, serta dengan pemerintah, Pusat dan Pemerintah Kabupaten Sragen.

Meningkatkan sarana dan prasarana serta infrastruktur yang menunjang seperti membangun wahana permainan air, kereta wisata dan fasilitas-fasilitas penunjang lain, sehingga menarik dan menciptakan kenyamanan bagi pengunjung. Di samping itu guna memudahkan akses bagi pengun-jung, khususnya di ketiga klaster (Manyarejo, klaster Bukuran dan klaster Ngebung), dipandang penting memperlebar dan memperbaiki jalan agar kendaraan besar seperti bus yang mengangkut rombongan wisatawan dapat masuk.

Menyediakan dan mengembangkan berbagai amenitas (sarana penunjang) pariwisata yang dapat memberikan kenyamanan kepada wisatawan yang berkunjung ke berbagai objek dan daya tarik wisata khususnya yang ada di museum pendukung 
Manyaerejo, klaster Bukuran dan klaster Ngebung.

\section{c. Strategi Strength and Threats}

Strategi ST merupakan strategi yang menggunakan kekuatan (Strength) untuk mengatasi berbagai hambatan atau ancaman (Threats) yang ada. Strategi pengembangan wisata Situs Sangiran ke depan dapat dirumuskan dengan memanfaatkan berbagai kekuatan yang ada dalam menjawab berbagai hambatan dan tantangan yang dihadapi. Adapun strategi dimaksud adalah pengadaan formasi pegawai yang handal khususnya untuk mengisi pegawai yang ada di museum Klaster Manyaerejo, klaster Bukuran dan museum klaster Dayu. Dalam pengisian pegawai, hendaknya mempertimbangkan profesionalitas sesuai kepakaran yang dibutuhkan termasuk didalamnya untuk jabatan satuan pengamanan.

Membentuk Kelompok Sadar Wisata dengan menanamkan prinsipprinsip Sapta Pesona yang terdiri atas aman, tertib, bersih, sejuk, indah, ramah tamah, dan kenangan. Kelompok sadar wisata ini bertugas antara lain, memberikan penyuluhan, pengarahan dan penjelasan kepada masyarakat, tentang manfaat pembangunan pariwisata bagi upaya menunjang pembangunan perekonomian daerah serta meningkatkan kesejahteraan masyarakat di sekitar Sangiran.

Pengembangan pariwisata membutuhkan peran serta investor untuk ikut serta mengembangkan pariwisata (Siagian 2008:94). Keberadaan investor sangat penting untuk diadakan karena memberikan dampak langsung bagi pengembangan kepariwisataan, salah satu cara yang dapat dilakukan dengan memberikan informasi yang akurat kepada investor mengenai potensi unggulan pariwisata Situs Sangiran.
Pengembangan kepariwisataan membutuhkan dana yang sangat besar agar dapat berdaya saing dan mampu mengikuti perkembangan tren pariwisata masa kini.

\section{d. Strategi Weaknesses and Threats}

Strategi WT merupakan strategi yang meminimalkan kelemahan-kelemahan (weaknesses) untuk menghindari hambatanhambatan atau ancaman (threats). Mempertimbangkan berbagai kelemahan, kemudian berusaha untuk mencari solusinya, maka strategi pengembangan destinasi wisata Sangiran yang akan datang dapat dilakukan strategi, yaitu khusus Museum Pendukung Manyarejo dipandang segera untuk membangun tempat parkir, karena parkir di sepanjang jalan menuju museum akan mengganggu keamanan dan Kenyamanan para pemakai jalan lainnya.

Menyadari pariwisata adalah suatu sistem, maka pengembangan di daerah ini perlu diarahkan, dengan melibatkan semua pihak, baik masyarakat, pihak pemerintah dan pihak swasta. Mempertimbangkan pula, secara kelembagaan Situs Sangiran berada di bawah kewenangan pemerintah pusat, maka harus ada pembagian kewenangan yang jelas siapa melakukan apa. Hal ini penting dilakukan untuk menghindari duplikasi kewenangan dengan pemerintah kabupaten dan pemerintah provinsi setempat.

Dalam pengembangan pariwisata, SDM merupakan salah satu kunci yang menentukan perkembangan pembangunan di suatu kawasan atau daerah wisata. Oleh karena itu SDM yang dimiliki perlu dikelola secara tepat sesuai dengan karakteristiknya meliputi. a. peningkatan kemampuan secara ilmu pengetahuan, peningkatan keterampilan maupun dalam penguasaan sumber daya yang ada. $b$. peningkatan pendidikan, baik formal 
maupun informal yang menekankan pada profesionalisme, sehingga kualitas kerja yang dihasilkan sesuai dengan tuntutan kualitas yang mampu bersaing di era kompetif pada masa sekarang ini.

Guna mencegah terjadinya eksploitasi berupa pencurian fosil-fosil Situs Sangiran, maka dipandang penting pemerintah melakukan upaya preventif dalam bentuk penyuluhan tentang arti penting warisan budaya secara terus menerus kepada masyarakat Sangiran. Di samping itu, perlu menjalin kerja sama dengan pihak kepolisian setempat untuk menindak secara tegas pelaku pelanggaran tersebut untuk memberikan pelajaran efek jera kepada pelaku.

\section{KESIMPULAN}

Dengan memahami berbagai faktor kondisi baik potensi, kekuatan dan peluang, serta ancaman dalam pengembangan daya tarik wisata budaya Situs Manusia Purba Sangiran, maka dapat disimpulkan sebagai berikut.

1. Dipandang penting mewujudkan peningkatkan potensi dan kualitas produk wisata, dengan penekanan nilai-nilai edukatif dan informatif, disamping rekreatif yang menghibur. Daya tarik wisata budaya Sangiran, memiliki nilai-nilai komersial yang mampu menarik minat wisatawan berdatangan dengan jaminan, bahwa waktu dan biaya yang telah dikeluarkan seimbang dengan pengalaman yang diperoleh setelah mengunjungi objek tersebut.

2. Upaya peningkatan penyelenggaraan promosi wisata, melalui pembentukan image, bahwa Sangiran sebagai salah satu daya tarik wisata budaya yang unik (distinctive), menarik (atraktif) dan informatif, sehingga memiliki nilai jual yang tinggi (selling point) atau layak untuk dikunjungi, oleh karena itu, berbagai upaya peningkatan kerja sama dengan stake holders, termasuk dengan biro perjalanan wisata merupakan suatu keharusan yang segera diwujudkan.

3. Upaya pengembangan pariwisata, keterlibatan masyarakat lokal sebagai tuan rumah memegang peranan yang sangat penting dalam pembangunan pariwisata,. agar mereka terlatih dan mampu menciptakan usaha pariwisata yang berkelanjutan. Lebih lanjut pelibatan masyarakat dalam perencanaan merupakan kebijakan yang sangat baik yang akan memotivasi masyarakat lokal untuk melakukan proteksi terhadap lingkungannnya yang akan dipakai sebagai pendukung pariwisata. Dalam konteks demikian itu, masyarakat harus diposisikan sebagai subjek sebagai pelaku pembangunan pariwisata, bukan objek.

4. Untuk mencegah terjadinya pencurian warisan budaya berupa fosil-fosil Situs Sangiran yang dilakukan oleh penduduk setempat, maka hukum harus ditegakan sesuai dengan ketentuan yang ada. Dalam hal ini, sangsi hukum perlu diterapkan kepada pelaku pencurian, karena melanggar Undang-undang RI No 11 Tahun 2010 Tentang Cagar Budaya.

\section{DAFTAR RUJUKAN}

Anonim, 2002. Draf final Report Penyusunan Detail Engineering Museum Purbakala Sangiran. Semarang: CV Rekayasa Jati Mandiri. 
Bryson, John M. 2007. Perencanaan Strategis Bagi Organisasi Sosial. Yogyakarta: Pustaka Pelajar.

Gitosudarmo. Indriyo. 2001. Manajemen Strategis. Edisi Pertama. Yogyakarta: PT. BPFE.

Ismayanti. 2010. Pengantar Pariwisata. Jakarta: GRASINDO PT. Gramedia Widiasarana Indonesia.

Maulana Adin. 2014. Tinjauan Kesadaran Merek Pariwisata Indonesia "Wonderful Indonesia". Buletin Penelitian Destinasi Pariwisata, edisi Desember 2014. Pusat Penelitian dan Pengembangan Kebijakan Kepariwisataan. Badan Pengembangan Sumber Data Pariwisata \& Eekonomi Kreatif. Kementerian Pariwisata dan Ekonomi Kreatif.

Marpaung, Happy 2002. Pengetahuan Kepariwisataan. Bandung: Penerbit Alfabeta

Moleong, J. Lexy. 2000. Metode Penelitian Kualitatif, Bandung: PT Remaja Rosdakarya.

Nuryanti., Wiendu. (2004). Culture, Tourism, and Poverty Alleviation Case Study: Borobaitudur Temple, Central Java - Indonesia, Seminar on Cultural Tourism and Poverty Alleviation (tidak diterbitkan).

Pendit, Nyoman S., 2003. Ilmu Pariwisata Sebuah Pengantar Perdana, Jakarta: PT. Pradnya Paramita.

Pitana,I Gde dan Ir. Putu G. Gayatri, M.Si. 2005. Sosiologi Pariwisata, Yogyakarta: Penerbit Andi.
, dan I Ketut Surya Diarta, SP., MA. 2009. Pengantar Ilmu Pariwisata, Yogyakarta: Penerbit Andi.

Rangkuti, Freddy. 2008. Analisis SWOT Teknik Membedah Kasus Bisnis. Jakarta: PT Gramedia Pustaka.

Siagian, Sondang P. 2008 . Manajemen Stratejik. Jakarta : Bumi Aksara.

Suranti, Ratna. 2005.: "Pariwisata Budaya dan Peran Masyarakat”. Disampaikan dalam Seminar Workshop Wisata Budaya bagi Kelompok Masyarakat Provinsi DKI Jakarta, pada tanggal 12 Juli 2005.

Undang-Undang Republik Indonesia Nomor 10 Tahun 2009, Tentang Kepariwisataan. Jakarta: Sekretariat Negara Republik Indonesia.

Undang-Undang Republik Indonesia Nomor 11 Tahun 2010, Tentang Cagar Budaya. Jakarta: Sekretariat Negara Republik Indonesia.

Widianto, Harry. dkk, 2011. Rencana Induk Pelestarian Kawasan Situs Sangiran. Kementerian Pendidikan dan Kebudayaan, Direktorat Jenderal Kebudayaan, Balai Pelestarian Situs Manusia Purba Sangiran. Tidak Diterbitkan. 